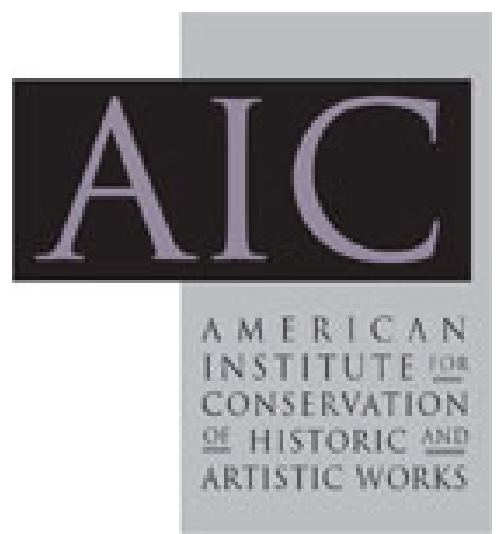

Assessment of Deterioration in Archaeological Wood from Ancient Egypt

Author(s): Robert A. Blanchette, John E. Haight, Robert J. Koestler, Pamela B. Hatchfield, Dorthea Arnold

Source: Journal of the American Institute for Conservation, Vol. 33, No. 1 (Spring, 1994), pp. 55-70

Published by: The American Institute for Conservation of Historic \& Artistic Works

Stable URL: http://www.jstor.org/stable/3179670

Accessed: $21 / 06 / 201108: 58$

Your use of the JSTOR archive indicates your acceptance of JSTOR's Terms and Conditions of Use, available at http://www.jstor.org/page/info/about/policies/terms.jsp. JSTOR's Terms and Conditions of Use provides, in part, that unless you have obtained prior permission, you may not download an entire issue of a journal or multiple copies of articles, and you may use content in the JSTOR archive only for your personal, non-commercial use.

Please contact the publisher regarding any further use of this work. Publisher contact information may be obtained at http://www.jstor.org/action/showPublisher?publisherCode=aic.

Each copy of any part of a JSTOR transmission must contain the same copyright notice that appears on the screen or printed page of such transmission.

JSTOR is a not-for-profit service that helps scholars, researchers, and students discover, use, and build upon a wide range of content in a trusted digital archive. We use information technology and tools to increase productivity and facilitate new forms of scholarship. For more information about JSTOR, please contact support@jstor.org.

The American Institute for Conservation of Historic \& Artistic Works is collaborating with JSTOR to digitize, preserve and extend access to Journal of the American Institute for Conservation. 


\title{
ASSESSMENT OF DETERIORATION IN ARCHAEOLOGICAL WOOD FROM ANCIENT EGYPT
}

\author{
ROBER T A. BLANCHETTE, JOHN E. HAIGHT, ROBERT J. KOESTLER, \\ PAMELA B. HATCHFIELD, AND DORTHEA ARNOLD
}

\begin{abstract}
Archaeological wood from many different ancient Egyptian tombs and diverse areas along the Nile Valley was examined to identify the type of deterioration present and to evaluate the current condition of the wood. Three different forms of degradation were identified and appear frequently among wooden cultural properties excavated from these ancient tombs; soft rot and brown rot fungal decay and a nonbiological form of deterioration. Decay by soft rot and brown rot fungi was prevalent in wood with extensive areas of degradation. Soft rot was characterized by cavities formed within the secondary cell walls. Cells with advanced stages of soft rot had numerous coalescing cavities that caused remaining cell wall layers to collapse. Ultrastructural observations of wood decayed by species of brown rot in the class Basidiomycetes revealed swollen, porous cell walls that were disrupted, leaving a granular mass of residual wall material. Many objects also suffered from a nonbiological type of deterioration. Cracks and fissures were evident within secondary walls, and cells delaminated at middle lamellae regions. Chemical deterioration from interactions among wood surfaces, limestone, gypsum, sodium chloride, and moisture are proposed as a cause of this degradation. The types of deterioration identified are common among objects that have survived in these unique physicochemical environments. Knowledge of these different degradation processes and the resulting condition of the wood provide important information that can now be used for developing appropriate conservation and restoration procedures.
\end{abstract}

\section{INTRODUCTION}

Wood deteriorates rapidly from a variety of different biotic processes when exposed to moderate environmental conditions. In situations of environmental extremes, however, such as a dry tomb chamber buried beneath rock or soil, wood decomposition is impeded. Archaeological wood that has survived exceedingly long periods of time may have been protected from the most aggressive wooddestroying fungi, but inevitably some abiotic or biotic deterioration takes place. While the deterioration and conservation of waterlogged wood have been the focus of much study, until recently far less attention has been given to archaeological wood from dry environments. Understanding the mechanisms of deterioration as well as the condition of the artifact at the ultrastructural level makes it possible to tailor treatment, physical supports, and environmental conditions most appropriate for the long-term preservation of archaeological woods. In addition, information on the decay present can provide insights into past microbiological events as well as past physicochemical and environmental conditions of the site.

Different abiotic and biotic forms of deterioration result in distinct changes within wood cells (Blanchette et al. 1990; Fengel 1991; Kirk and Cowling 1984; Liese 1970; Singh and Butcher 1990). These chemical and morphological degradation patterns can be used to determine the type of decay and the causal agent. Information obtained from previous studies of microbial degradation have provided a useful classification system for fungal and bacterial degradation of wood. Soft, brown, and white rot are broad categories of different types of decay caused by fungi. Within each group, further differentiation can be made depending 

PAMELA B. HATCHFIELD, AND DORTHEA ARNOLD

on the degradative mode of action and cell wall decay patterns (Blanchette 1991; Eriksson et al. 1990; Singh and Butcher 1990). Bacteria degrade wood differently from fungi, and ultrastructural studies have revealed distinct forms of attack (Nilsson and Daniel 1983; Daniel and Nilsson 1986; Nilsson and Singh 1983; Singh and Butcher 1990). Tunneling and erosion bacteria degrade wood, causing minute tunnels or eroded zones within cell walls, whereas other species of bacteria may attack only pit membranes. As new investigations focus on the different forms of bacterial attack, more specific classification systems will undoubtedly be utilized. Recent reviews of microbial degradation have been published (Blanchette et al. 1990; Eriksson et al. 1990; Highley and Illman 1991), and this information can be used as criteria to evaluate decay in archaeological wood and other wood of historic value (Blanchette et al. 1990; Blanchette et al. 1991b).

Abiotic factors are also responsible for degrading wood, but our knowledge of these processes is meager due not only to the long time period required for significant degradation to become apparent but to the masking effects of the ever-present microbial population. In a study of wood from the high Arctic that had been buried or frozen for 20-60 million years, microorganisms were found to be excluded but deterioration was still evident (Blanchette et al. 1991a; Obst et al. 1991). A slow acid hydrolysis has been postulated that gradually degraded cell wall carbohydrates and modified residual lignin. In situations where wood is in contact with high concentrations of acid or alkaline compounds, deterioration may be substantial even after a few decades (Blanchette et al. 1991b; Parameswaran 1981). Although the presence of metal ions in wood is typically considered to . have a preservation effect, degradation of wood can also occur from products of metal corrosion. Iron or other metal corrosion products can weaken wood and cause significant cell wall alterations (Baker 1974; Marian and Wissing
1960; Parameswaran and Borgin 1980). Metal ions are active catalysts promoting chemical reactions that initiate a nonbiological type of cell wall degradation (Baker 1974; Blanchette and Simpson 1992; Keepax 1975). Moisture and soluble chlorides accelerate the corrosion process and the deterioration of wood. In certain circumstances, metal corrosion not only causes extensive cell wall degradation but produces iron or other metal pseudomorphs that display a replica of the woody cell wall (Blanchette and Simpson 1992).

Many wooden cultural properties from ancient Egypt have been preserved for thousands of years in extraordinarily good condition. Wood fragments from various objects have been used in past research to identify wood species and to detect changes that may have occurred in the wood. In these studies, the macroscopic structure of the wood samples selected for study was sound and appeared intact (Borgin et al. 1975; Nilsson and Daniel 1990). No microbial degradation was found by Borgin et al. (1975), but mechanical damage to the wood cell walls was evident. Separations within the secondary walls and fractures in middle lamellae were observed. In the study by Nilsson and Daniel (1990) of wood samples from ancient tombs, a weakening of the wood revealed by cracks and delaminations within cell walls was observed in one sample; however, the source of this deterioration was not identified. In another sample, a soft rot form of fungal degradation was evident within the secondary wall layers of the wood cells.

Observations of wooden artifacts in museum collections of ancient Egyptian art clearly demonstrate that not all wooden objects are in good condition. Many cultural properties have substantial deterioration. In a preliminary study, objects that appeared to display different stages of decay were selected for ultrastructural examination (Blanchette et al. 1991b). Advanced stages of decomposition were apparent in all of the selected woods. 
TABLE 1

WOOD CULTURAL PROPERTIES EXAMINED FROM THE ANCIENT EGYPTIAN COLLECTIONS AT THE MUSEUM OF FINE ARTS, BOSTON, AND THE METROPOLITAN MUSEUM OF ART

\begin{tabular}{|c|c|c|}
\hline MUSEUM & $\begin{array}{l}\text { ACCESSION } \\
\text { NUMBER }\end{array}$ & DESCRIPTION \\
\hline \multirow{8}{*}{$\begin{array}{l}\text { Museum of } \\
\text { Fine Arts, } \\
\text { Boston }\end{array}$} & 01.7431 & $\begin{array}{l}\text { Mask from a coffin lid. From Abydos, Tomb D115, XVIII Dynasty (1570-1293 B.C.). } \\
\text { Brick-lined tomb shaft }\end{array}$ \\
\hline & 02.813 & Toilet box with sliding cover. From Fayum (A.D. 1000-2000) \\
\hline & 13.2 .781 & Bed leg, Kerma (ca. 1600 B.C.). Earthen tumulus burial \\
\hline & 13.3464 & $\begin{array}{l}\text { Portrait statuette of a girl. From Giza (2336, Serdab 3), V Dynasty (2524-2400 B.C.). } \\
\text { Limestone tomb chamber }\end{array}$ \\
\hline & $21.897-21.903$ & $\begin{array}{l}\text { Offering wooden stand with four calcite Hes vases. From Bersha Pit 10A, XII Dynasty } \\
(1991-1784 \text { B.C.). Limestone tomb chamber }\end{array}$ \\
\hline & 29.1860 & $\begin{array}{l}\text { Anthropoid outer coffin of Gem-hap. From Giza, G7652A Saite (664-525 B.C.). } \\
\text { Limestone catacomb }\end{array}$ \\
\hline & 72.4360 & Head of canopic jar \\
\hline & 21.811 & $\begin{array}{l}\text { Coffin of Satmeket. From Bersha Pit 12, XII Dynasty (1991-1784 B.C.). Limestone tomb } \\
\text { chamber }\end{array}$ \\
\hline \multirow{9}{*}{$\begin{array}{l}\text { Metropolitan } \\
\text { Museum of } \\
\text { Art }\end{array}$} & 12.187 .52 & Couch frame. From Tarkhan. I Dynasty (3100-2890 B.C.). \\
\hline & 25.3 .7 & Outer coffin of Menkheperra. From Thebes, Deir el-Bahri. XXI Dynasty (1000-945 B.C.) \\
\hline & 26.2 .4 & Statue of the scribe of Mitry. From Saggara, V Dynasty (2340 B.C.) \\
\hline & 26.2 .5 & Statue of the wife of Mitry. From Saggara, V Dynasty (2340 B.C.) \\
\hline & 26.9 .3 & $\begin{array}{l}\text { Statue from tomb of Kaiemsenuwy. From Saqqara, VI Dynasty } \\
(2345-2181 \text { B.C.) }\end{array}$ \\
\hline & 27.9 .5 & Statue of a courtier. From Sagqara, VI Dynasty (2363-2275 B.C.) \\
\hline & 32.1.133 & Coffin of Akhtoy. From Lisht, XII Dynasty (1962-1786 B.C.) \\
\hline & $96.4 .1 \mathrm{a}$ & $\begin{array}{l}\text { Coffin of Tabakenkhonsu. From Thebes, Deir el- Bahri, XXVI } \\
\text { Dynasty (663-525 B.C.) }\end{array}$ \\
\hline & Beam-MMA & $\begin{array}{l}\text { Boat timber reused as a beam in transportation. From Lisht (1950 B.C.). Embedded in } \\
\text { mud and gypsum mortar }\end{array}$ \\
\hline
\end{tabular}

In our study we examined a large number of different wooden objects from the collections of ancient Egyptian art in the Museum of Fine Arts, Boston, and the Metropolitan Museum of Art, New York, that displayed visual evidence of deterioration. Ultrastructural observations were used to determine the type of decay that was present, evaluate the current condition of the wood, and provide general knowledge of deterioration common to woods found in dry archaeological sites. The results presented here should serve as a guide for types of decomposition that can be expected in woods from similar environments.

\section{EXPERIMENTAL METHODS}

Cultural properties made from wood located in the ancient Egyptian collections of the Museum of Fine Arts, Boston (MFA) and the Metropolitan Museum of Art (MMA) were examined for evidence of deterioration. Objects with visual characteristics of decay were selected for sampling (table 1). Small sections of deteriorated wood were removed from the surface of each object and prepared for ultrastructural observations. Segments from each sample were cut and immediately fixed in $0.5 \%$ potassium permanganate $\left(\mathrm{KMnO}_{4}\right)$ for 90 minutes, washed with several rinses of distilled water, and dehydrated 


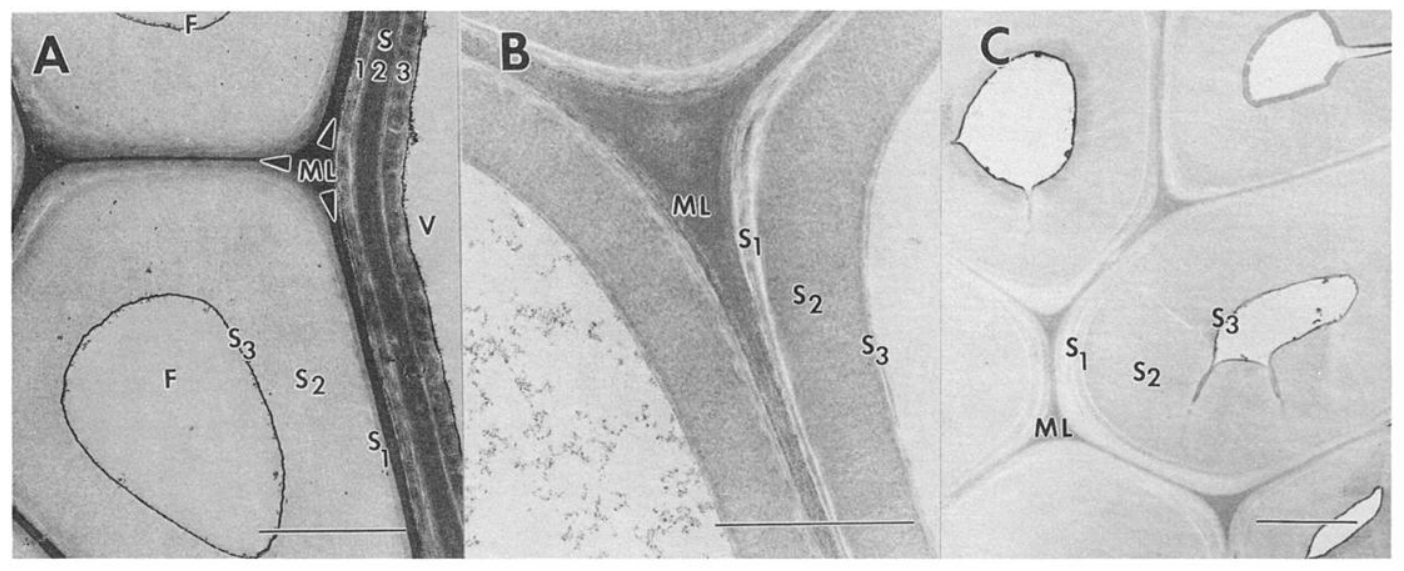

Fig. 1. Transverse sections of (A) sound modern maple (Acer); (B) spruce (Picea); and (C) boxwood (Buxus), showing various morphological regions of woody cell walls. The dark, electron dense regions between cells is the compound middle lamellae (ML), and the secondary wall has $S_{1}, S_{2}$, and $S_{3}$ layers. (A) Maple is an angiosperm with vessels $(\mathrm{V})$ and fibers $(\mathrm{F})$ evident in the wood. The secondary wall layers of vessels are approximately equal in size, whereas fiber walls have a large $S_{2}$ region. (B) Tracheids of the gymnosperm, spruce, showing middle lamellae and secondary walls. (C) Wood from the angiosperm, boxwood, is unusual in that it contains small vessel elements (not shown in figure) and fiber-tracheids. The fiber-tracheids have an exceedingly thick $S_{2}$ layer of the secondary wall. Bar $=5 \mu \mathrm{m}$

through a graded acetone series. Samples were further dehydrated into $100 \%$ Quetol embedding solution for 24 to 48 hours. The solution consisted of Quetol 651, nonenylsuccinic anhydride, nadic methyl anhydride, and 2,4,6,tri(dimethylaminoethyl) phenol in a 15:20:10:0.45 ratio. Polymerization was at $74^{\circ} \mathrm{C}$ for approximately 8 hours. Transverse sections of the wood (100-120 nm) were cut with a diamond knife, mounted on 300-mesh copper grids, viewed, and photographed with a Hitachi 600 transmission electron microscope (TEM). Sound wood of maple (Acer), spruce (Picea), and boxwood (Buxus) were also embedded and sectioned for comparison to the deteriorated wood.

Elemental analyses were carried out on two ancient samples, where sufficient wood was available for destructive analysis, and two modern samples by multielemental inductively coupled plasma atomic emission spectroscopy (ICPAES). The samples were oven-dried, ground in a Wiley mill, and ashed at $485^{\circ} \mathrm{C}$ for 10-12 hours. The ash was equilibrated with $2 \mathrm{M}$ $\mathrm{HCl}$ at room temperature $\left(24^{\circ} \mathrm{C}\right)$ and analyzed by ICPAES following procedures of Dahlquist and Knoll (1978) and elemental concentrations are reported as micrograms per gram (see table 2).

\section{RESULTS AND DISCUSSION}

\subsection{WOOD ULTRASTRUCTURE}

The patterns of wood deterioration were determined by studying transverse sections of degraded woods with transmission electron microscopy. These methods allowed high magnification observations to be made of the woody cell wall with good resolution. Sound wood from modern samples are presented to familiarize the reader with the ultrastructure of unaltered woods (fig. 1). Wood from angiosperms (hardwoods such as maple and oak) or gymnosperms (conifers such as pine and spruce) are composed of different types of cells 
Fig. 2. Cultural properties from ancient Egyptian tombs showing extensive deterioration. (A) Statue of the scribe of Mitry, $V$ Dynasty (2340 B.C.) from Saqqara, Metropolitan Museum of Art, New York (MMA 26.2.4). Large zones of decayed wood were removed and filled with plaster during restoration work completed more than $\mathbf{5 0}$ years ago. (B) Statue of the wife of Mitry (MMA 26.2.5) excavated from the same tomb.

Deterioration is severe, especially at the lower portions of the statue that were in contact with the tomb floor.

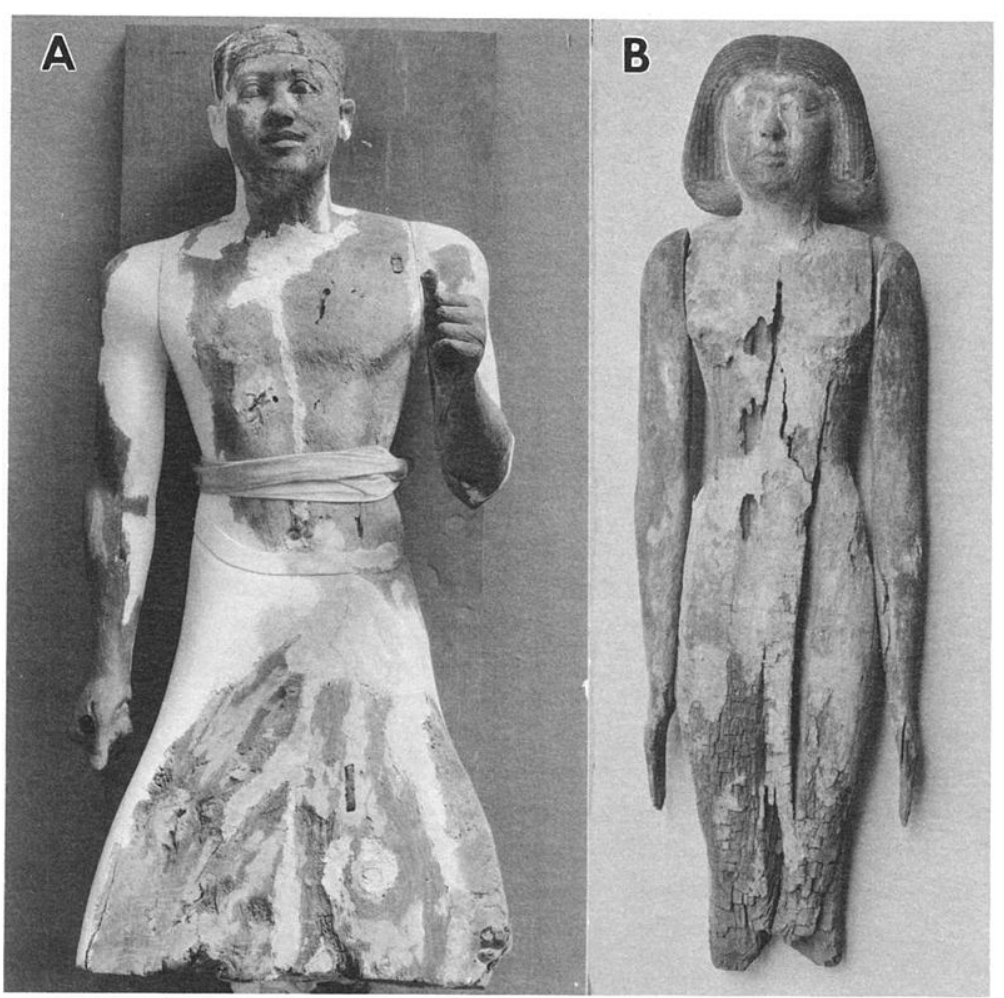

\subsection{GENERAL OBSERVATIONS OF WOODEN CULTURAL PROPERTIES}

Objects made from wood are well represented in museum collections of ancient Egyptian art. Statues, coffins, furniture, and other cultural properties have been found in ancient tombs in remarkably good condition considering they have been buried for thousands of years. Deterioration, however, is common among these objects, and it is rare to find wooden cultural properties that are totally free of decay. In many collections, the true condition of artifacts may be masked by materials such as wax initially used to facilitate their removal from burial environments, or by early restoration techniques designed to improve the aesthetic appearance of the object for display purposes. Only limited study has been initiated on the effects of some of these treatments on the condition of ancient woods (Hatchfield and Koestler 1987). Nor has the effect of various 
restoration treatments on the fragile condition of the altered, deteriorated wood been investigated. Extensive restoration, completed more than $\mathbf{5 0}$ years ago, is shown in a photograph of the statue of the scribe of Mitry (MMA 26.2.4) taken during the restoration process (fig. 2a). The completed work shows little evidence of decay that was so prevalent in the object. In comparison, the decayed statue of Mitry's wife (MMA 26.2.5), found in the same tomb with MMA 26.2.4 and not restored, reveals the true condition of the wood (fig. 2b). The unaltered statue allows an evaluation of the events that influenced the deterioration and provides the opportunity to learn more about the aging process of wood, microbial interactions, and the past physical environment of the tomb. Many objects we examined had advanced decay, whereas others had decay that was restricted to the surface or found in localized areas of the wood (fig. 3). The deteriorated remains of gesso and paint are also present on many objects (fig. 2a-b).

\subsection{NONBIOLOGICAL DETERIORATION}

Samples of wood taken from the outer surfaces of many objects were found to have wood cells that displayed numerous cracks and fractures within cell wall layers. Separations were frequent within the compound middle lamella region (fig. 4). This electron dense region between cells appeared granular and lacked integrity. In some cells with alterations, the middle lamella was extensively fragmented, and secondary walls were detached from adjacent cells (fig. 4b). Observations of detached cells showed remnants of the middle lamellae adhering to the $S_{1}$ region of the secondary wall. Cracks and separations were also evident in secondary wall regions. The separations often formed large voids in the wall or occurred in a parallel series of small separations within the $S_{2}$ layer. Extraneous materials were frequently observed in cell lumina (fig. $4 a-b$ ).
Previous investigators who examined the ultrastructure of wooden objects from ancient Egypt reported checks and fractures occurring in otherwise sound wood cells (Borgin et al. 1975; Nilsson and Daniel 1990). A general weakening of the wood structure was apparent, causing delamination and loosening of wall layers. The fissures and other alterations were thought to be exaggerated due to the preparation procedures used for ultrastructural observations (Borgin et al. 1975; Nilsson and Daniel 1990).

From the objects that we examined, nine showed some evidence of cell wall weakening with delaminations in the secondary wall and fissures occurring in the middle lamella regions. No evidence of microorganisms was found in these altered cells. The degradation patterns, when compared to the various forms of decay that have been evaluated, most closely resembled alterations associated with a delignification process. This type of damage may occur from degradation by white rot fungi that selectively remove lignin (Blanchette et al. 1990; Blanchette 1991; Eriksson et al. 1990), photodegradation by ultraviolet light (Chang et al. 1982; Kuo and Hu 1991), or other nonbiological forms of deterioration (Blanchette et al. 1991a; Kass et al. 1970; Parameswaran 1981).

Decay by white rot fungi did not occur since no evidence of fungal hyphae or other characteristics of wood decay by white-rotters was evident. In addition, the conditions of these burial sites containing limestone and alkaline $\mathrm{pH}$ conditions are not conducive to fungi in the class Basidiomycetes that cause a white rot (Blanchette et al. 1990). It is unlikely that these objects were exposed to ultraviolet radiation in amounts that would induce photo-oxidation processes. The most plausible explanation for this deterioration appears to be chemical reactions occurring when wood is in contact with limestone, gesso, or various salts over long periods of time. Unfortunately, little is known about the nonbiological degradative processes 
Fig. 3. (right) Deterioration in objects from ancient Egyptian tombs. (A) and (B) Mask from a coffin lid, XVIII Dynasty (15701293 B.C.) from Abydos Tomb D115, currently in the Museum of Fine Arts, Boston (MFA 01.7431). Front view is shown in (A) with deteriorated gesso and paint. The back side of the mask (B) exhibits advanced stages of decay throughout the wood. (C) Outer coffin of Gem-hap (MFA

29.1860) from Giza (664-525

B.C.), showing deterioration of coffin surface. (D) Statue of a girl (MFA 13.3464), V Dynasty (2524-2400 B.C.) from Giza, with advanced deterioration that has led to severe surface defects.

Fig. 4. (below) Transmission electron micrographs of transverse sections from the mask from a coffin lid (A) and (C) (MFA 01.7431, see fig. 3.A-B) and bed leg (B) (MFA 13.2.781), showing a nonbiological form of deterioration that affected the exterior portions of the wood. (A) and (B) Delaminated wood cells with cracks and fissures in the middle lamella (ML) region. Large voids are present in cell corners (CC). Cell walls appear swollen and have separations within the secondary wall layers (S). Parallel series of separations appear within the expanded $S_{2}$ layer (arrows). Extraneous material is evident, partially filling the cell lumina ( $\left.{ }^{\star}\right)$. (C) Affected cells detach from adjacent cells with remnants of degraded middle lamellae $(\mathrm{ML})$ adhering to the secondary walls $(\mathrm{S})$

(arrowheads) $\mathrm{Bar}=5 \mu \mathrm{m}$
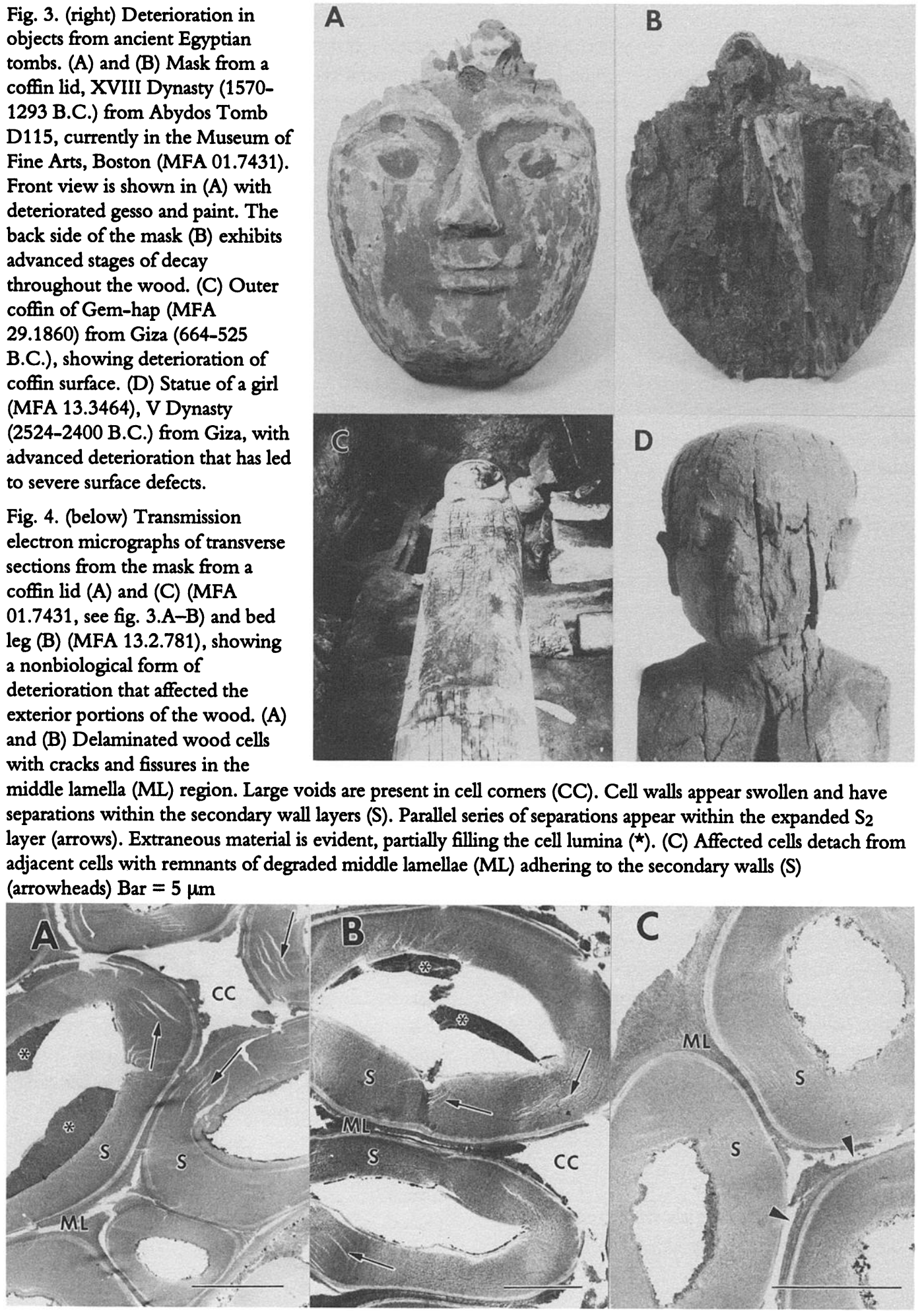
TABLE 2

ELEMENTAL COMPOSITION OF SOUND MODERN WOOD AND ARCHAEOLOGICAL WOOD FROM ANCIENT EGYPT

\begin{tabular}{|l|l|l|l|l|l|l|l|l|l|l|l|}
\hline \multirow{2}{*}{ SOURCE } & \multicolumn{10}{|l|}{ ELEMENTAL COMPOSITION OF WOODS $(\mu \mathrm{g} / \mathrm{g})$} \\
\cline { 2 - 18 } & $\mathrm{Al}$ & $\mathrm{B}$ & $\mathrm{C}_{2}$ & $\mathrm{Cu}$ & $\mathrm{Fe}$ & $\mathrm{K}$ & $\mathrm{Mn}$ & $\mathrm{Mg}$ & $\mathrm{N}_{2}$ & $\mathrm{P}$ & $\mathrm{Zn}_{\mathrm{n}}$ \\
\hline Sound Cednus sp. & 44 & 3 & 258 & 10 & 12 & 59 & 8 & 38 & 17 & 34 & 8 \\
\hline Sound Buxus sp. & 5 & 1 & 694 & 3 & 19 & 650 & 10 & 267 & 62 & 69 & 5 \\
\hline $\begin{array}{l}\text { Beam excavated from Lisht } \\
\text { (MMA) }\end{array}$ & 268 & 68 & 61,750 & 5 & 153 & 321 & 18 & 3,189 & 60,893 & 72 & 6 \\
\hline Coffin (MFA 21.811) & 58 & 60 & 6,084 & 4 & 39 & 372 & 48 & 317 & 1095 & 39 & 5 \\
\hline
\end{tabular}

that take place when wood surfaces are in contact with alkaline substances for thousands of years. Moisture, crucial to initiating reactions, was apparently intermittently present in many tombs. The migration of salts into wood also occurred during burial. Elemental analyses of two samples of wood, one from a limestone burial chamber and the other a beam used in transportation, showed high concentrations of sodium and calcium within the wood (table 2). The exceedingly high concentrations of sodium and other salts found in the beam demonstrate the levels that accumulate in wood when it is buried in contact with gypsum plaster.

When high concentrations of alkali are used in the pulping process of wood for papermaking, delignification results. The alkali treatment of wood combined with heat causes a dissolution of hemicellulose and lignin from wood, resulting in a cellulose-rich pulp. Wood in contact with low concentrations of alkaline substances may also be affected. Surface deterioration has been found in wood that was in contact with potash for 40 years. The degradation caused a delamination of wood cells and a general dissolution of lignin. The cells appeared partially swollen and sustained cracks and fissures within the secondary wall. Potassium chloride crystals were deposited on surfaces between cells and within cell walls. In areas where potassium chloride crystals accumulated, a total hydrolysis of wall material was evident (Parameswaran 1981). A similar type of deterioration has been reported previously where alkali substances were in contact with wood for several years within a historic building (Blanchette et al. 1991b).

Surface deterioration identified in the ancient Egyptian wood examined mimics the chemical deterioration patterns observed when high concentrations of alkaline substances come in contact with wood. Limestone or gesso may serve to initiate this nonbiological form of degradation when moisture was present within the tombs. Although concentrations of alkaline substances may be low, exposure for exceedingly long periods of time may have significant effects. High salt concentrations were present in two samples used for elemental analyses (table 2). These accumulations suggest that moisture from flooding, heavy rains, or other sources percolated down into the burial sites, causing various salts to migrate into the wood. The presence of sodium chloride frequently occurs within limestone in the Nile Valley, and physicochemical conditions of Egyptian archaeological sites have previously shown that long-term chemical reactions promoted by the presence of both sodium chloride and moisture affect plaster and painted murals within tombs (Burns et al. 1989).

The corrosive action of elevated salt concentrations also appears to contribute to wood deterioration (Wilkins and Simpson 1988). These high concentrations of salt pose serious concerns for conservators and may result in 
water absorption if humidity and temperature are not controlled. Without proper safeguards, surface deterioration may continue, albeit slowly, within excavated wood if moisture is present. Additional study of interactions among wood, moisture, sodium chloride, ancient gypsum-base plasters (and impurities) as well as limestone burial sites needs to be considered to understand fully the process of this nonbiological deterioration.

\subsection{BIOLOGICAL DEGRADATION}

In addition to areas of limited surface deterioration, many objects had extensive degradation throughout large areas of the wood (figs. 1-2). Macroscopically, the degraded wood appeared brown with little integrity remaining. Sections made from the various degraded objects showed that cell walls were decayed by fungi. Two distinct forms of decay were evident. Some objects had decay with characteristics of soft rot, whereas others were decayed by brown rot fungi.

\subsubsection{SOFT ROT}

Decay by soft rot fungi can be identified by the presence of longitudinal cavities that occur within the secondary wall layers of wood cells (Blanchette et al. 1990; Eriksson et al. 1990). In transverse sections, the cavities appear as round holes within the cell walls. In some of the wood samples examined, a typical soft rot form of decay was evident. Numerous holes were observed within the secondary walls, with remnants of fungal hyphae present within the cavities (fig. 5a-b). An electron dense area was observed around the cavities within the walls (fig. 5c). Cells with relatively few small diameter cavities represented early stages of decay (fig. 5a), whereas cells with numerous holes throughout the secondary wall represented late stages (fig. $5 b-d$ ). Holes within secondary walls often coalesced, forming large voids (fig. 5d). The middle lamella was occasionally disrupted. Cells with advanced soft rot lost much of their integrity, and the wood was extremely weak. Soft rot, when it has advanced to this stage of degradation, has removed most if not all of the woods' original strength properties (Hoffmeyer 1976).

An unusual form of soft rot was evident in one object (MMA 27.9.5). Cavities did not form in the thick layer of the secondary wall but were located within the innermost regions of this layer (fig. 5e-f). The thick secondary wall occasionally had small penetration holes (fig. 5f), but even after advanced soft rot, this part of the cell wall resisted decay. These cells appear to have characteristics common to tension wood. Tension wood is formed on the upper surface of leaning hardwood trees but can also occur in nonleaning tropical trees (Panshin and de Zeeuw 1970). Tension wood cells have a thick secondary wall layer that has been termed a gelatinous layer. The microfibrillar orientation of cellulose and the chemical composition of this layer are different from normal wood. A more crystalline form of cellulose has also been identified from the gelatinous layer (Wardrop and Dadswell 1955). The cavities within the cell wall were located within the $S_{2}$ and $S_{1}$ regions and were more elongate than typical soft rot cavities. Numerous coalescing cavities resulted in disrupted middle lamellae and detached remnants of cell walls (fig. 5f).

Soft rot fungi are most frequently associated with wood in contact with excessive moisture, conditions that exclude other more aggressive wood destroying fungi. Recently, it has been shown that soft rot fungi are prevalent in wood with low moisture or in environments with high pH (Blanchette et al. 1990; Blanchette and Simpson 1992). In these unusual environments, soft rot fungi progressively attacked the wood, causing a slow degradation whenever minimum conditions for growth were met. The extent of decay can be substantial over time, as demonstrated in a study of wood from Tumulus MM in Gordion, Turkey, where enormous logs of Cedrus and Juniperus (trees with significant decay resistance [Scheffer and Cowling 1966]) were 


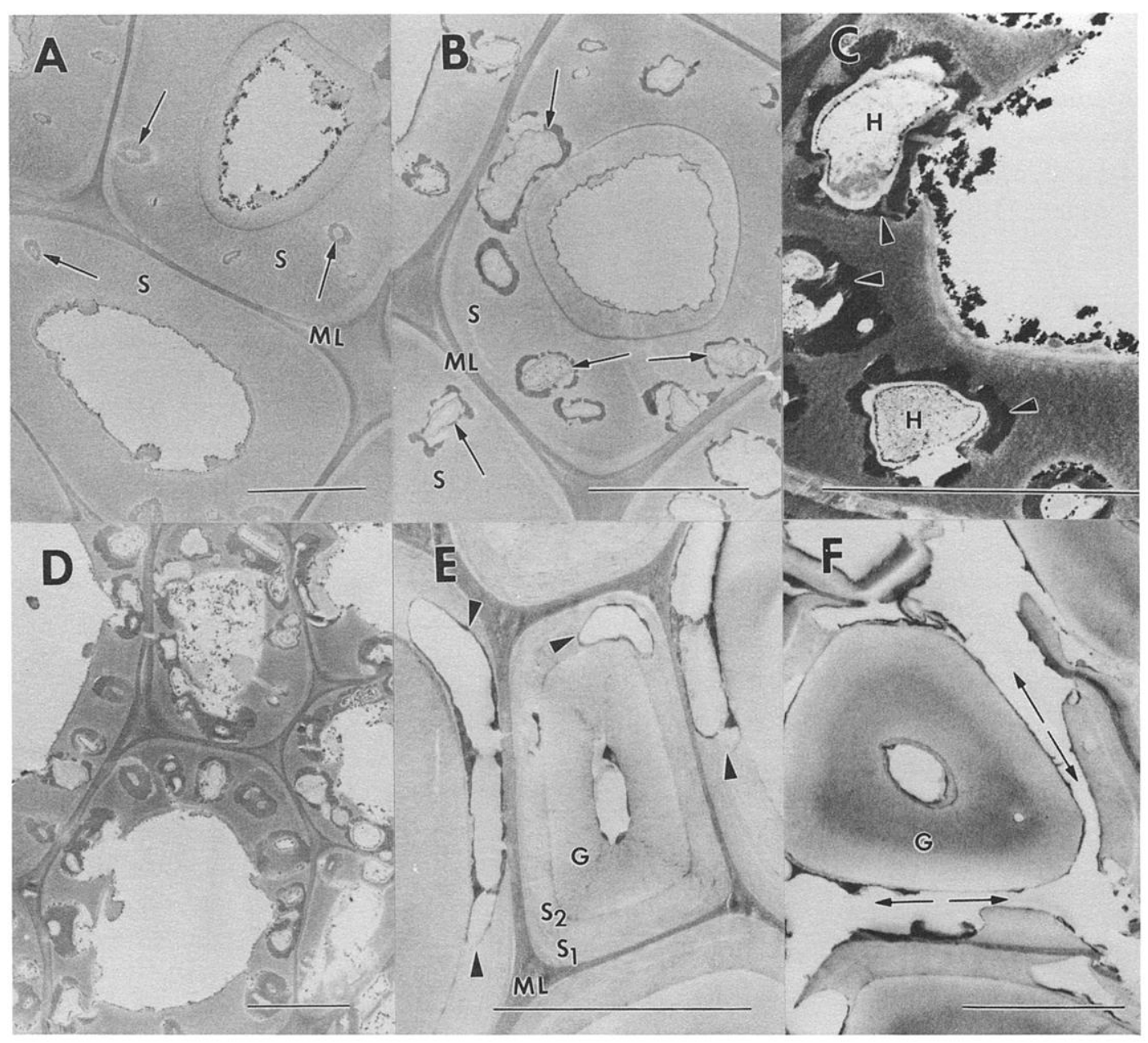

Fig. 5. Transmission electron micrographs showing soft rot cavities within transverse sections of cell walls from objects in the Museum of Fine Arts, Boston: (A) MFA 21.899; (B) MFA 01.7431; (C) and (D) MFA 21.897; and in the Metropolitan Museum of Art: (E) and (F) MMA 27.9.5. (A) Incipient stages of decay showing small cavities within the secondary wall layers (S) (arrows). (B) Large cavities (arrows) within the secondary wall (S), with remnants of fungal hyphae located within the cavities. (C) Soft rot cavities within the cell wall have a large central void with fungal hyphae $(\mathrm{H})$ present. The area of the secondary wall around the degraded hole is extremely electron dense (arrowheads). (D) Advance stages of decay, with numerous cavities throughout secondary wall layers. Cavities coalesce, forming large holes within the cell wall that reduce wood strength and integrity. Middle lamellae regions remain relatively free of attack but often fragment due to the lack of intact secondary wall material. (E) An unusual form of soft rot with cavities in the interior portions of the woody cells. The thick wall layer within cells resembles the gelatinous layer $(G)$ found in tension wood. Cavities (arrowheads) are restricted to the reduced $S_{1}$ and $S_{2}$ regions of the cell wall and appear elongated. (F) Cells with advanced decay have eroded $S_{1}$ and $S_{2}$ layers (arrows) and fragmented middle lamellae. The thick gelatinous layer $(G)$ is not degraded except for small diameter cavities that resemble hyphal penetration sites. $\mathrm{Bar}=5 \mu \mathrm{m}$ 
decayed extensively by soft rot fungi over a 2,500-year period under very limiting moisture conditions (Blanchette et al. 1991b; Blanchette and Simpson 1992).

\subsubsection{BROWN ROT}

Not all objects with extensive degradation were decayed by soft rot fungi. Observations made from sections of several other objects were found to be degraded by brown rot fungi. Wood cell walls from the decayed samples sustained a general loss of wood integrity, causing secondary walls and middle lamellae to appear swollen, porous, and distorted (fig. $6 a-c$ ). In cells with advanced decay, secondary cell walls disintegrated into a granular mass of residual wall material (fig. 6d). The cell corner regions of the middle lamellae remained relatively intact, but the zone of middle lamella between cells was severely disrupted (fig. 6c-d). In many areas of the wood, the cell walls fragmented into minute particles that filled cell lumina.

Remnants of fungal hyphae were present in all woods examined.

Brown rot fungi cause a diffuse depolymerization of cellulose in wood, resulting in significant strength losses during incipient stages of decay (Blanchette et al. 1990). As decay progresses, polysaccharides are degraded, leaving residual wall material that consists primarily of modified lignin. The cell walls of brownrotted wood have poor integrity, and wood can be easily crushed to a dustlike powder. This type of decay raises serious concerns for removing the object from the burial site without damage and for identifying proper conservation methods needed to stabilize the wood. Earlier in the century, archaeologists and conservators had few means of assessing damage to artifacts other than visual examination, and used the best materials and technology available in their efforts to preserve them. Opinions were, as they are today, strong about the expected appearance of objects for exhibition. A beautiful appearance indicated a sound object. However, we know that treatments such as those shown in figure 2 destroy much of the original wood and introduce the possibility of additional physical and chemical alterations that could have detrimental effects. Although advances in conservation practices for archaeological wood have been made in recent years (Barclay 1981; Schniewind 1990), an appropriate method of treating deteriorated wood without possible adverse affects has not been identified. Knowledge of the subcellular condition of the wood and characteristic physical and chemical properties is essential for developing specific treatments that will ensure long-term conservation and protection of these important cultural properties. Research into the possible long-term effects of gypsum, polyfillers, or other conservation products used in the conservation of wood is especially warranted. Although damage as a result of relatively short-term contact between archaeological wood and alkaline fill materials has not been identified, alternatives should be considered, such as glass microballoons in acrylic resins (Hatchfield 1986). This substitution avoids exposing archaeological wood to both excessive moisture and alkaline substances, which could promote accelerated deterioration in localized areas.

Wood decayed by brown rot fungi was frequently encountered in the archaeological wood examined from ancient Egypt. Moisture is essential for brown rot to occur and had to have been present in sufficient quantities for decay to progress to the advanced stages observed. Excavation photos indicate that the most severe decay was located in wooden objects in contact with the tomb floor or along walls (Zayed 1956). These sites of moisture accumulation may have occurred relatively soon after the tomb was closed and when propagules of brown rot fungi were still viable. Evidence of termites and other insects in some burial sites suggests the possibility that decay fungi could be introduced at later times by insects that entered the tomb and disseminated the brown rot fungi. 


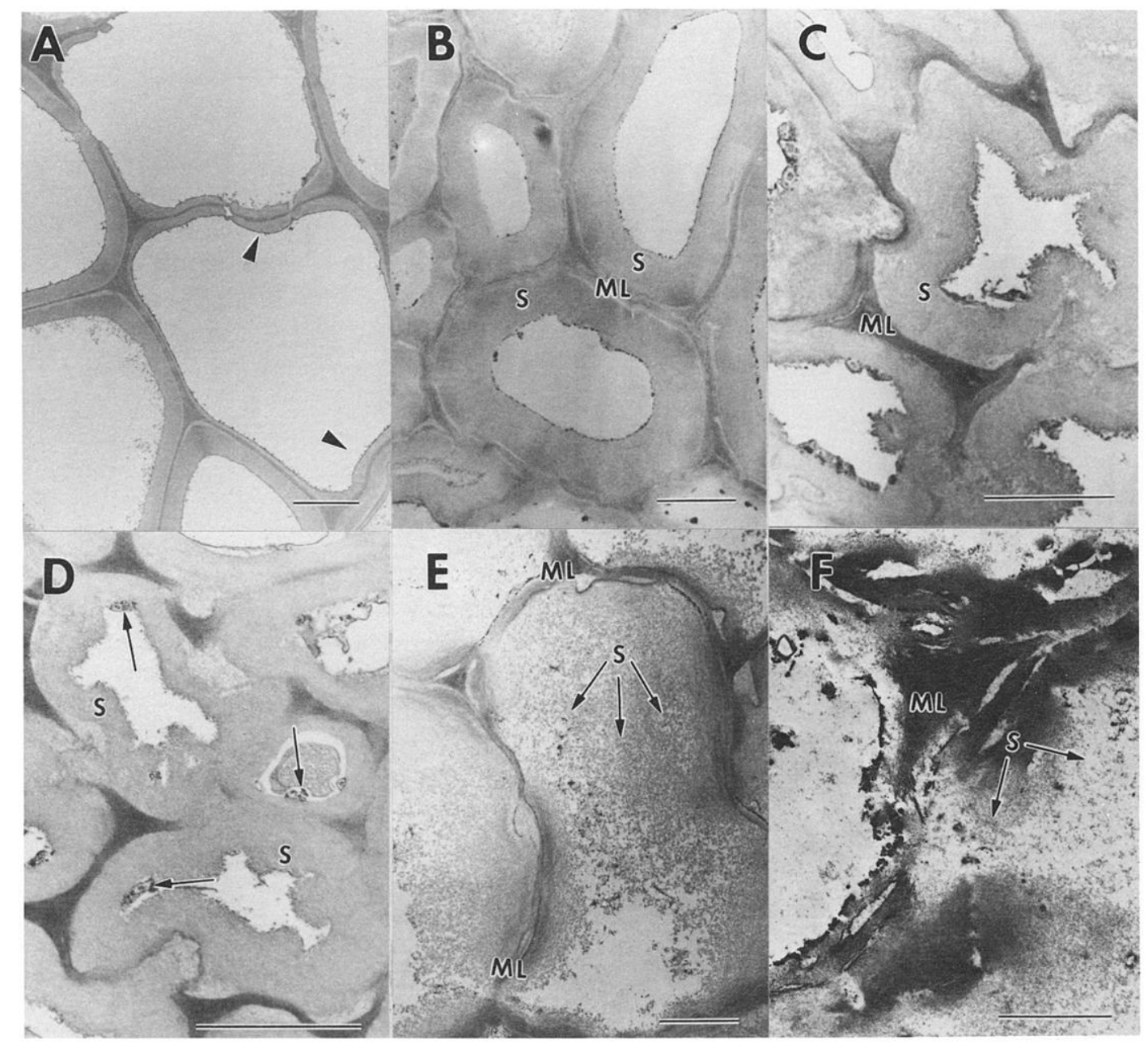

Fig. 6. Transmission electron micrographs of transverse sections showing different stages of brown rot in samples from the Museum of Fine Arts, Boston, and the Metropolitan Museum of Art: (A) MFA 02.813; (B) MMA 12.187.52; (C) MMA 26.2.4; (D) MMA 26.2.5; (E) MMA 32.1.133; (F) MFA 29.1860. (A) Incipient stages of decay in earlywood cells with some loss of integrity as evident in cell walls that bend and have lost some of their original shape (arrowheads). (B) A more advanced stage of brown rot, with secondary walls (S) exhibiting a swollen appearance and convoluted middle lamellae (ML) with reduced electron density. (C) and (D) Secondary walls (S) have become extended and appear to have a granular consistency. Cell walls have altered shapes, with areas of the middle lamellae between cells distorted and disrupted. Cell corner regions of some cells remain but have a diffuse, swollen appearance. The secondary wall layers can still be identified with remnants of fungal hypha in cell lumina (arrows). (E) In advanced stages of decay the secondary wall layers have been disrupted, and residual secondary wall substances ( $S$, arrows) are dispersed. $A$ residual middle lamellae can be seen among degraded particulate matter. (F) Severe deterioration is evident in totally disrupted cells. Degraded secondary walls (S) and middle lamella (ML) have fragmented into minute dustlike particles. Bar $=5 \mu \mathrm{m}$ 


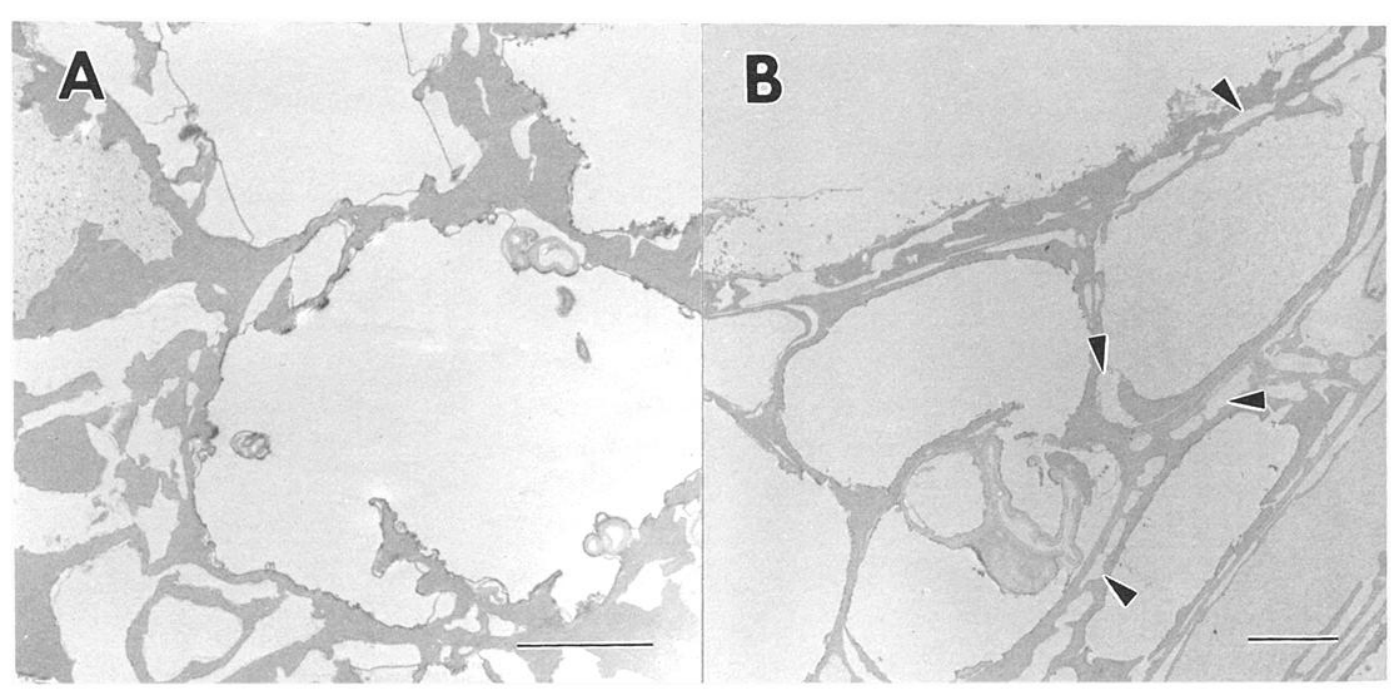

Fig. 7. Transmission electron micrographs of sections from object MFA 13.3464 (fig. 3D) that displayed unusual surface deterioration. (A) Cell walls do not have the typical cell wall layers evident, and electron dense middle lamellae regions are not distinct. Structures that resemble hyphae are present in voids that appear to correspond to cell lumina. (B) Cell walls without distinct morphological features are present and cavities (arrowheads) are found within residual cell walls. These cavities represent a soft rot type of decay, but subsequent treatments, possibly made during excavation, have destroyed the original characteristics of the woody cell wall. Bar $=5 \mu \mathrm{m}$

\subsubsection{DETERIORATION PATTERNS MASKED BY TREATMENT}

Not all deterioration observed in wood from museum collections can be attributed to biotic or abiotic agents during entombment. An object exhibiting unusually severe deterioration (fig. 7a-b) showed cell wall characteristics that did not resemble any known forms of deterioration. Cell wall layers were not distinct and appeared as disrupted amorphous strands (fig. $7 \mathrm{a}-\mathrm{b})$. Some cavities were present in the altered wall material. Although no records of treatments made to the wood during excavation in 1913 exist, it is apparent that the wood had been modified. Many different treatments utilized during the late 19 th to early 20 th century for consolidation could be responsible for the unusual condition (Hatchfield and Koestler 1987; Mace and Winlock 1916). Most likely, the wood statuette was decayed to a considerable extent by soft rot fungi, as evidenced by the cavities within the cell walls. However, the severely altered state of the wood cells suggests that subsequent treatments accentuated the defect and resulted in what appears to be an unusual form of deterioration. A proper understanding of wood degradation and the devastating effects that some treatment can have on deteriorated wood should help to avoid this problematic situation.

\section{CONCLUSIONS}

The results from this study demonstrated that different forms of deterioration are prevalent in wood from archaeological sites in Egypt. Each type of decay has distinct morphological characteristics that enable identification by comparing them to model examples of decay processes. Additional information obtained during investigations that focus on physicochemical environmental factors may help to associate the different types of deterioration with specific 

PAMELA B. HATCHFIELD, AND DORTHEA ARNOLD

environmental and substrate conditions. With this information, it appears possible to predict the type of wood deterioration that could be encountered in future excavations, allowing appropriate conservation schemes to be planned and implemented. For cultural properties already accessioned into museums, proper conservation methods need to be evaluated and tested for the different forms of deterioration common to these objects.

The results presented here call for some reevaluation of conventional storage methods for certain classes of organic materials. Organics have been typically housed at relative humidities around $50 \%$. However, two factors prompt us to reconsider this estimate: the damaging effects of salts and alkaline materials present in some archaeological woods and the likelihood that fungi will become active at higher relative humidities. An understanding of the nature of these deterioration processes leads to the conclusion that certain archaeological wood collections should be housed at lower relative humidities than previously assumed. Increased knowledge of wood deterioration and interacting chemical, environmental, and physical factors should prove to be useful for continuing the development of new, improved methods for conserving archaeological wood.

\section{ACKNOWLEDGEMENTS}

The authors thank Peter Lacorara, assistant curator, Department of Egyptian, Nubian, and Ancient Near Eastern Art, the Museum of Fine Arts, Boston, for assistance in obtaining samples.

\section{REFERENCES}

Baker, A. J. 1974. Degradation of wood by products of metal corrosion. USDA Forest Service Research Paper FPL-229.

Barclay, R. 1981. Wood consolidation on an eighteenth century English fire engine. Studies in Conservation 26:133-39.
Blanchette, R. A. 1991. Delignification by wooddecay fungi. Annual Review of Phytopathology 29:38198.

Blanchette, R. A., K. R. Cease, A. R. Abad, T. A. Burnes, and J. R. Obst. 1991a. Ultrastructural characterization of wood from Tertiary fossil forests in the Canadian Arctic. Canadian Joumal of Botany 69:56068.

Blanchette, R. A., K. R. Cease, A. R. Abad, R. J. Koestler, E. Simpson, and G. K. Sams. 1991b. An evaluation of different forms of deterioration found in archaeological wood. Intemational Biodeterioration 28:3-22.

Blanchette, R. A., T. Nilsson, G. Daniel, and A. Abad. 1990. Biological degradation of wood. In Archaeological wood: Properties, chemistry, and preservation, ed. R. M. Rowell and R. J. Barbour. Advances in Chemistry series 225. Washington, D.C.: American Chemical Society. 141-74.

Blanchette, R. A., and E. Simpson. 1992. Soft rot and wood pseudomorphs in an ancient coffin $(700$ B.C.) from Tumulus $\mathrm{MM}$ at Gordion, Turkey. International Association of Wood Anatomists Bulletin, n.s. 13:201-13.

Borgin, K., N. Parameswaren, and W. Liese. 1975. The effect of aging on the ultrastructure of wood. Wood Science and Technology 9:87-98.

Burns, G., K. M. Wilson-Yang, and J. E. Smeaton. 1989. Archaeological sites as physicochemical systems: Macroarchaeometry of the tomb of Nefertari, Valley of the Queens, Egypt. In Archaeological chemistry IV, ed. R. O. Allen. Advances in Chemistry series 220. Washington D.C.: American Chemical Society. 289-310.

Chang, S. T., D.N.S. Hon, and W. C. Feist. 1982. Photo degradation and photo protection of wood surfaces. Wood and Fiber Science 14:104-17.

Dahlquist, R. L., and J. W. Knoll. 1978. Inductively coupled plasma-atomic emission spectrometry: Analyses of biological materials and soils for trace and ultra-trace elements. Applied Spectroscopy 32:1-30.

Daniel, G. F., and T. Nilsson. 1986. Ultrastructural observations on wood degrading erosion bacteria. International Research Group on Wood Preservation. Document IRG/WP/1283.* 
Eriksson, K.-E., R. A. Blanchette, and P. Ander. 1990. Microbial and enzymatic degradation of wood and uood components. New York: Springer-Verlag.

Fengel, D. 1991. Aging and fossilization of wood and its components. Wood Science and Technology 25:15377.

Hatchfield, P. B. 1986. Note on a fill material for water sensitive objects. Joumal of the American Institute for Conservation 25:93-96.

Hatchfield, P. B., and R. J. Koestler. 1987. Scanning electron microscopic examination of archaeological wood microstructure altered by consolidation treatments. Scanning Microscopy 1:1059-69.

Highley, T. L., and B. L. Illman. 1991. Progress in understanding how brown-rot fungi degrade cellulose. Biodeterioration Abstracts 5:231-44.

Hoffimeyer, P. 1976. Mechanical properties of softrot-decayed Scots pine with special reference to wooden poles. In Soft rot in utility poles. Swedish Wood Preservation Institute 117. Stockholm, Sweden: Swedish Wood Preservation Institute. 2.12.55 .

Kass, A., F. F. Wangaard, and H. A. Schroeder. 1970. Chemical degradation of wood: The relationship between strength retention and pentosan content. Wood and Fiber Science 2:31-39.

Keepax, C. 1975. Scanning electron microscopy of wood replaced by iron corrosion products. Joumal of Archaeological Science 2:145-50.

Kirk, T. K., and E. B. Cowling. 1984. Biological decomposition of solid wood. In The chemistry of solid wood, ed. R. M. Rowell. Advances in Chemistry series 207. Washington D.C.: American Chemical Society. 455-87.

Kuo, M-1, and N. Hu. 1991. Ultrastructural changes of photodegradation of wood surfaces exposed to UV. Holzforschung 45:347-53.

Liese, W. 1970. Ultrastructural aspects of woody tissue disintegration. Annual Review of Phytopathology 8:231-57.

Mace, A. C., and H. E. Winlock. 1916. The tomb of Senebtisi at Lisht. New York: Metropolitan Museum of Art.
Marian, J. E., and A. Wissing. 1960. The chemical and mechanical deterioration of wood in contact with iron: Part 2, Chemical decomposition. Svensk Pappersmassetidning 63:98-106.

Nilsson, T. 1973. Studies on wood degradation and cellulolytic activity of microfungi. Studia Forestalia Suecica Nr. 104.

Nilsson, T., and G. F. Daniel. 1983. Tunnelling bacteria. International Research Group on Wood Preservation. Document IRG/WP/1186.*

Nilsson, T., and G. Daniel. 1990. Structure and the aging process of dry archaeological wood. In $\mathrm{Ar}$ chaeological wood: Properties, chemistry, and preservation, ed. R. M. Rowell and R. J. Barbour, Advances in Chemistry series 225. Washington, D.C.: American Chemical Society. 67-86.

Nilsson, T., and A. P. Singh. 1983. Cavitation bacteria. International Research Group on Wood Preservation. Document IRG/WP/1235.*

Obst, J. R., N. J. McMillan, R. A. Blanchette, D. J. Christensen, D. M.Crawford, O. Faix, J. S. Han, T. A. Kuster, L. L. Landucci, R. H. Newman, R. C. Pettersen, V. H. Schwandt, and M. F. Wesolowski. 1991. Characterization of Canadian Arctic fossil woods. In Tertiary fossil forests of the Geodetic Hills, ed. R. L. Christie and N. J. McMillan. Geological Survey of Canada, Bulletin 403. Axel Heiberg Island, Arctic Archipelago: Geological Survey of Canada. 123-46.

Panshin, A. J., and C. de Zeeuw. 1970. Textbook of wood technology, 3d ed. New York: McGraw-Hill.

Parameswaran, N. 1981. Micromorphology of spruce timber after long-term service in a potash store house. Holzforschung 39:149-56.

Parameswaran, N., and K. Borgin. 1980. Micromorphological and analytical study of an ancient pinewood from Cyprus containing metallic copper. Holzforschung 34:185-90.

Scheffer, T. C., and E. B. Cowling. 1966. Natural resistance of wood to microbial deterioration. Annual Review of Phytopathology 4:147-70.

Schniewind, A. P. 1990. Consolidation of dry archaeological wood by impregnation with thermoplastic resins. In Anchaeological wood: Properties, chemistry 

PAMELA B. HATCHFIELD, AND DORTHEA ARNOLD

and preservation, ed. R. M. Rowell and R. J. Barbour. Advances in Chemistry series 225. Washington, D.C.: American Chemical Society. 361-71.

Singh, A. P., and J. A. Butcher. 1990. Bacterial degradation of wood cell wall: A review of degradation patterns. International Research Group on Wood Preservation. Document IRG/WP/1460.*

Wardrop, A. B., and H. E. Dadswell. 1955. The structure and properties of tension wood.

Holzforschung 9:97-103.

Wilkins, A. P., and J. A. Simpson. 1988. Difibring of roof timbers. Joumal of the Institute of Wood Science 11:121-25.

Zayed, A. H. 1956. Deux statues de scribe accroupi en bois (Mitri) dans les Magasins de Saggara. In Trois etudes D'Egyptologie. Le Cave: Imprimerie Dar elHana. 14-21.

*Available from the IRG Secretariat, Box 5607, S11428 Stockholm, Sweden.

\author{
SOURCES OF MATERIALS \\ Quetol \\ Nissan EM Co., Ltd. \\ Shinjyuku \\ Tokyo, Japan
}

ROBERT A. BLANCHETTE, Ph.D., is a professor in the Department of Plant Pathology at the University of Minnesota. He has written two books, several review chapters, and numerous scientific articles on microbial degradation processes of wood. Current research activities focus on biodeterioration in archaeological wood from terrestrial and aquatic environments and on developing appropriate conservation methods for decayed wood. Address: Department of Plant Pathology, University of Minnesota, 495 Borlaug Hall, 1991 Upper Buford Circle, St. Paul, Minn. 55108.

JOHN E. HAIGHT holds a bachelor's degree and is a research associate working with $R$. A. Blanchette. With an expertise in electron microscopy, he is involved with many research projects studying the ultrastructure of biodeteriorated wood. Address as for Blanchette.
ROBERT J. KOESTLER has a Ph.D. in the field of cellular biology from the City University of New York. He has worked in the museum field for 18 years, 8 of them managing a scanning electron microscope facility at the American Museum of Natural History in New York, and the balance at the Metropolitan Museum of Art, New York, where he is currently research scientist. His more than 60 publications cover aspects of the biological and conservation sciences. His most recent research concerns development and evaluation of conservation strategies for preserving artistic and historic materials, especially those affected by biodeterioration. Address: Objects Conservation, Metropolitan Museum of Art, 1000 Fifth Ave., New York, N.Y. 100280198.

PAMELA B. HATCHFIELD holds a B.A. from Vassar College and an M.A. and diploma from New York University in art history and conservation. She is currently an associate conservator of objects and sculpture at the Museum of Fine Arts, Boston. She has served as conservation assistant at the Metropolitan Museum of Art and site conservator at Apis Bull Sanctuary, Memphis and Western Cemetery, Giza, Egypt. Address: Museum of Fine Arts, Boston, 465 Huntington Ave., Boston, Mass. 02115.

DORTHEA ARNOLD is the Lila Acheson Wallace Curator of the Egyptian Art Department at the Metropolitan Museum of Art. She has excavated extensively in Lisht as well as other locations in Egypt. Address: Egyptian Department, Metropolitan Museum of Art, 1000 Fifth Ave., New York, N.Y. 10028-0198.

Paper 20,260, Minnesota Agricultural Experiment Station, based on research conducted under Project 22-69. Received for review January 15, 1993. Revised copy received July 30,1993. Accepted for publication August 24, 1993. 